\title{
Online Games, Brain and Communication Ability
}

\author{
Ambyah Harjanto, Nurdin Hidayat, Mareyke Jessy Tanod, Apri Wahyudi, Dedi Irawan, Phong \\ Thanh Nguyen, E. Laxmi Lydia, K. Shankar
}

\begin{abstract}
This study outlines the literature relevant to the effects of online games issues and the positive and negative effects of online games on child brain and communicative ability. Recent study, online games are now increasingly used for purposes other that entertainment. These games play on role in fields as diverse as education, cognitive training, physical exercise, and rehabilitation. Using games, which is communicative essence are often considered effective in developing child communicative ability. In this review, the result from the literature review indicate a number of gaps in the present framework. As a result, can guide teachers and parents to be able to know the processes that occur in the online game for child.
\end{abstract}

Keywords : online game, brain, communication ability.

\section{INTRODUCTION}

Today, Internet is developing rapidly so that gadget users for both communication and entertainment facilities such as games are also growing rapidly. Playing game is an activity performed to make decisions, work together or competence who are trying to achieve goals regulated by rules [1]. Online game is a form of digital entertainment that is being preferred by all groups, especially child. Online game consumption makes parents worry will affect the brain development and communication skills of child.

Not all online games that are made will damage the performance of the child's brain. Many educational games are made even for therapeutic healing disorders in child. The study that was initiated by Feng et al. [2] shows that games can makes beneficial changes in perception, attention and spatial cognition. Game also gives child the opportunity to interact in the language studied.

Revised Manuscript Received on July 22, 2019.

Ambyah Harjanto, College of Teacher Training and Education PGRI Bandar Lampung, Lampung Indonesia. E-mail: cambyasoul@gmail.com

Nurdin Hidayat, College of Teacher Training and Education PGRI Bandar Lampung, Lampung Indonesia,Indonesia. E-mail: nurdinstkippgribl@gmail.com

Mareyke Jessy Tanod, College of Teacher Training and Education PGRI Bandar Lampung, Lampung Indonesia,Indonesia. E-mail: farakuan@gmail.com

Apri Wahyudi, College of Education Pringsewu, Lampung, Indonesia. E-mail: apriwahyudistitpringsewu@gmail.com

Dedi Irawan, College of Education Pringsewu, Lampung, Indonesia.

E-mail: dediirawanstitpringsewu@gmail.com

Phong Thanh Nguyen, Department of Project Management, Ho Chi Minh City Open University, Vietnam.

E. Laxmi Lydia, Vignan's Institute of Information Technology (A), Department of Computer Science and Engineering, Visakhapatnam, Andhra Pradesh, India.

K. Shankar, Department of Computer Applications, Alagappa University, India.
At certain times, game encourages and requires a lot of significant interaction between players. In online games, there is a form of collaboration and sharing of items that is one example of communication. Game can also be used for learning and acquiring second languages. If in school, child tends to be more difficult to communicate using a second language because when communicating students are already worried about the values and grammar rules [3-7]. For instance, chat log in online games provide opportunities for child to communicate authentically with other gamers.

Speaking is one of the basic language skills that must be mastered and the use is very significant for communication. Many linguists conduct experiments in encouraging child to be comfortable and not worry worry about making mistakes in learning language. Not only that, the game is developed for a meaningful purpose and requires a comprehensive understanding that triggers benefits in the game.

A lot of research reveals that second language learning will be better using games [8-12], of course games will also be very good if it is implemented in improving communication in the first language. By using games, students are more relaxed in communicating.

Playing game can be effective in developing students' communication skills because the communication process done is very dynamic because child is thoughtful, emotional and communicators. Game is not only the container of knowledge but also as the media to get ideas, concepts, thoughts, emotions and feelings expressed based on their own life experiences.

\section{DISCUSSION}

There are several types of approaches taken in this literature study : (1) Games can train child's brain abilities during playing game (2) Game can affect child's speaking abilities in language acquisition both first and second language acquisition.

\section{A. Game online for Brain Development}

In playing online game, Child has several stages starting from the visual stage to the stage when the child experience cognitive abilities. The stages are as follows.

\section{Sensory processing}

When the light from the gadget falls into the retina, there is an interaction of about 100 million special neurons to deliver information to parts of the brain through the optic nerve. Early visual system function such as brightness detection, edge detection, orientation detection, segmentation, shape perception, 


\section{Online Games, Brain and Communication Ability}

3D perception, motion detection, and color processing. Games that already have 3D format can ease the child to understand what they see. Because the development of child at a certain age still can not understand abstract $2 \mathrm{D}$..

\section{Attentional capture and visual selective attention.}

The visual system cannot process all information obtained from what the child sees. In processing the data flow, it requires a very large computational burden. However, the child's brain must analyze something that requires a process of decision making and that is usually followed by motor actions. This mechanism can help child in their daily lives. For example, child can be aware of objects that can make them stumble while walking or pay attention to vehicles approaching when crossing the road.

\section{Dividing attention, switching attention, and distributing attention.}

In playing game, child is given a simulation of several objects that emerge from certain locations and perform two or more tasks simultaneously and it requires divided attention. Of course, the distribution of attention requires speed and accuracy. Distributing attention in broad visual field allows child to see, recognize and distinguish between objects. So that we can know that the dynamic and complex visual characteristics of online game that requires the ability to maximize and divert attention very quickly.

\section{Memory}

In playing online games, memory has an important role so that online games has big infulence to train child's memories.

\section{Spatial cognition}

Spatial cognition is the ability to represent the spatial relationship between ourselves and the environment and between objects in the environment. This is important for many daily tasks, such as reading maps, navigating, solving geometry problems, and designing and building structures and machinery. Some spatial skills such as the ability to rotate objects mentally are highly correlated with mathematical skills.

\section{Emotion}

In playing online game, child will be more emotional. Being emotional is not always bad because if the emotion is trained, the child will be able to work under pressure as long as the stress level is not extravagantly high.

\section{Motor actions}

Most of the perceptual and cognitive processes carried out by the brain are perceptual to actions, which generally require good visuo-motor coordination. Visuo-motor coordination is the ability to use visual information to control and direct the motor system to complete tasks. This is a basic skill needed for daily activities that involve movement, such as walking, dressing, writing, driving, or playing sports. In online games, visuo-motor coordination is between hands and eyes. The eye controls the focus of attention and hands complete the task. Nearly every online game consists of dynamic and good visual presentations. So that online games can improve child's visuo - motor skills.

\section{Speed}

In playing online game, speed will certainly be very necessary, especially if the game contains racing or even war content. The speed of decision making and child's motor skill will be greatly helped by the existence of online games.

\section{B. Game online and communication skill}

Talking is more than producing words. It means that the speaker must know correct words, the amount of stress and intonation in the sentence, to use grammatical forms, to utilize the appropriate lexicon that the audience can understand. This is why speaking is not considered to be an act of only producing words, but that more complex the skill involves many actions, such as taking turns, questioning, using adequate pressure and intonation, and so on.

A lot of research states that communicative games can help child to obtain and improve child's communication skill. Online game is designed for users to communicate with other gamers. Because online game users are not limited to a country. child will use international languages to communicate. child who cannot communicate will be motivated to learn so they can play the game. It is different if a child learns language and communicates on the orders of the teacher or parent, usually it is assessed, watched and corrected. It will cause pressure on child in learning so that online games can be a means for child to improve their communication skill both in the first and second languages.

\section{CONCLUSION}

From the discussion above, it can be concluded that a lot of research has been done about online game. The research state that online game can improve and encourage child to communicate. But Largely it is still explorative, limited in scope and with very small sample sizes. Online game also contribute many positive things in the development of a child's brain, but it can only be done by certain people and games. Researchers need a lot of studios and more literature to determine which games are well used by child and how long it takes to develop child's brain abilities.

\section{REFERENCES}

1. Rixon, Steven. (1981). How to Use Games in Language Teaching. London: Macmillan.

2. Feng, J., Spence, I., (2008). How Video Games Benefit Yout Brain. URL http://meaningfulplay.msu.edu/proceedings2008/mp2008_ paper 76.pdf

3. L.A. Apanasyuk, E. Vladimirovna Smirnova, R. H. Mukhutdinov, A. Maseleno, The Problem of the Organization of Socio-Cultura Environment for Adaptation and Development of a Student-Migrant's Bilingual Identity in the Conditions of the Russian Higher Education, International Journal of Recent Technology and Engineering (IJRTE), Vol. 7, Issue 6S5, pp. 63-70, 2019.

4. O.N. Yarygin, A.A. Korostelev, L.G. Akhmetov, A.Maseleno, Modeling of Competence as a Tool of Goal Setting for Education in Modern Society, International Journal of Recent Technology and Engineering (IJRTE), Vol. 7, Issue 6S5, pp. 78-86, 2019.

5. B.A.Vladimirovna, A.A. Korostelev, R.H. Mukhutdinov, I.A. Shakirova, A.Maseleno, Formulation of the Problem of Mathematical Modeling of Accommodation of Basic Stations of Cellular Communication in Residential Territories for Students of It-Directions of Preparation, International Journal of Recent Technology and Engineering (IJRTE), Vol. 7, Issue 6S5, pp. 96-100, 2019 
6. B.A. Vladimirovna, A.A. Korostelev, O.L. Shepelyuk, A.E. Rodionova, I.N. Fardeeva, A.Maseleno, Reengineering of Business Processes of the Higher School: Its Prerequisites, International Journal of Recent Technology and Engineering (IJRTE), Vol. 7, Issue 6S5, pp. 101-104, 2019.

7. R.R. Vakhitov, A.E. Rodionova, E.V. Smirnova, R.H. Mukhutdinov, M.I. Arzhakova, A. Maseleno, Crisis of Higher Education in Russia, International Journal of Recent Technology and Engineering (IJRTE), Vol. 7, Issue 6S5, pp. 105-109, 2019.

8. Daniel, Kardefelt., Winther (2017). How does the time child spend using digital technology impact their mental well-being, social relathionship and physical activity: An evidance-focuced literature review. Italy: UNICEF.

9. Feng, J., Spence, I., \& Pratt, J (2007). Playing an action video game reduces gender differences in spatial cognition. Psychological Science, 18(10), 850-855.

10. Ratna Sari Dewi, Ummi Kultsum, dan Ari Armadi (2016). Using Communicative Games in Improving Students Speaking Skills. Canadian Center of Science and Education Vol 10 nu. 1.

11. Sara Prot, Craig A. Anderson, Douglas A. Gentile, Stephanie C. Brown, and Edward L. Swing (2014). The positive and negative effects of video game play. New York: Oxford University Press.

12. Zhu Deguang. (2012). Using Games to Improve Students Communicative Ability. Journal of Language Teaching and Research, Vol. 3, No. 4, pp. 801-805. 